\title{
A prolonged progressive lymphopenia with hypogammaglobulinemia after FCR treatment of chronic lymphocytic leukemia: case report and literature review
}

\author{
EWELINA GRYWALSKA ${ }^{\prime}$, AGATA SURDACKA ${ }^{l}$, MONIKA PIECZYKOLAN', \\ ELŻBIETA STAROSŁAWSKA ${ }^{2}$, KAROLINA OLSZEWSKA-BOŻEK ${ }^{1}$, JACEK ROLIŃSKI ${ }^{1}$ \\ ${ }^{1}$ Department of Clinical Immunology and Immunotherapy, Medical University of Lublin, Poland \\ ${ }^{2}$ Lublin Oncology Center, Poland
}

\begin{abstract}
The combination of two chemotherapeutic drugs, fludarabine and cyclophosphamide (FC), with the rituximab $(R T X)-F C R$ - in the treatment of chronic lymphocytic leukemia $(C L L)$ is associated with a high complete remission rate. In recent years FCR has become the first-line choice for CLL patients under 65 year of age. Delayed leucopenia has been described in rituximab-treated CLL patients. However among reported cases, the late onset and progressive lymphopenia was not noticed in individuals with $C L L$.

The present study reports the case of a 53-year-old Caucasian man who developed prolonged progressive lymphopenia after 18 weeks RTX treatment-free period. Irrespective of no drug intake, in 13-week follow up, the amount of B lymphocytes as well as the serum levels of Ig G decreased $193.22 \%$ and $20 \%$ reduction, respectively). Progressive neutropenia with hypogammaglobulinemia has constantly intensified leading to the necessity of gamma globulin supplementation and administration of granulocyte colony-stimulating factor $(G-C S F)$. The present findings suggests that FCR therapy in some individuals may lead to the induction of persistent alteration of the cellular and humoral immunity.
\end{abstract}

Key words: chronic lymphocytic leukemia, hypogammaglobulinemia, lymphopenia, neutropenia, rituximab.

(Centr Eur J Immunol 2012; 37 (3): 264-269)

\section{Introduction}

In recent years, chemoimmunotherapy combining rituximab (RTX) with fludarabine and cyclophosphamide (FCR) has become the first-line choice for persons suffering from chronic lymphocytic leukemia (CLL) [1]. The FCR regimen in treatment-naive CLL patients is associated with better outcome, especially in younger persons.

In the present study, we report a first case of a prolonged progressive lymphopenia with hypogammaglobulinemia after the end of CLL treatment with the use of FCR. The patient had no family history of immunodeficiency; before, during and in first six months after FCR treatment did not notice any infection or fever of unknown origin. During 7-month observation after the end of the treatment, the absolute number of neutrophils and B lymphocytes, and in consequence of which, immunoglobulin levels gradually decreased leading to the septic arthritis and necessity of gamma-globulin substitution and G-CSF admission.

\section{Case presentation}

The patient at the time of CLL treatment admission (October 2010) was a 52-year-old Caucasian. The laboratory tests were as follows: WBC, $117.9 \times 10^{3} / \mathrm{mm}^{3}(106.3 \times$ $\times 10^{3} / \mathrm{mm}^{3}$ lymphocytes $) ; \mathrm{Hg}-12.9 \mathrm{~g} / \mathrm{dl}$, hematocrit $38 \%$, platelet count $-276 \times 10^{3} / \mu \mathrm{l}$, C-reactive protein -

Correspondence: Ewelina Grywalska, Department of Clinical Immunology and Immunotherapy, Medical University of Lublin, Chodzki 4a, 20-093 Lublin, Poland, tel. +48 8175648 40, e-mail: ewelina.grywalska@gmail.com 

of chronic lymphocytic leukemia: case report and literature review
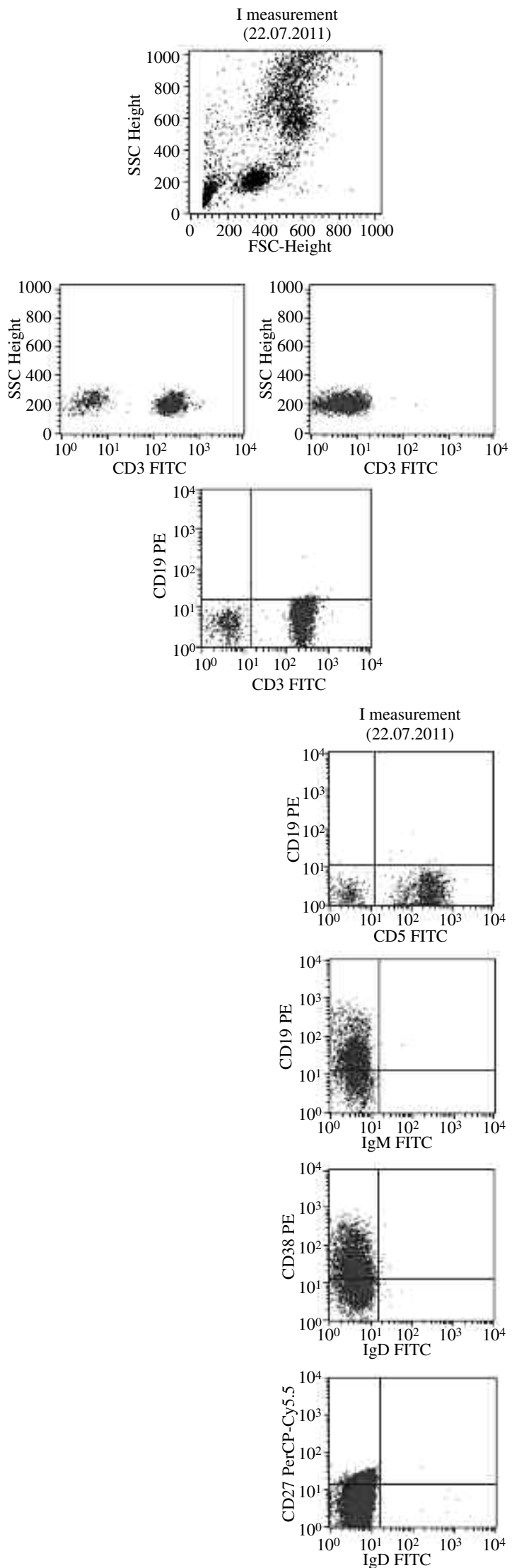
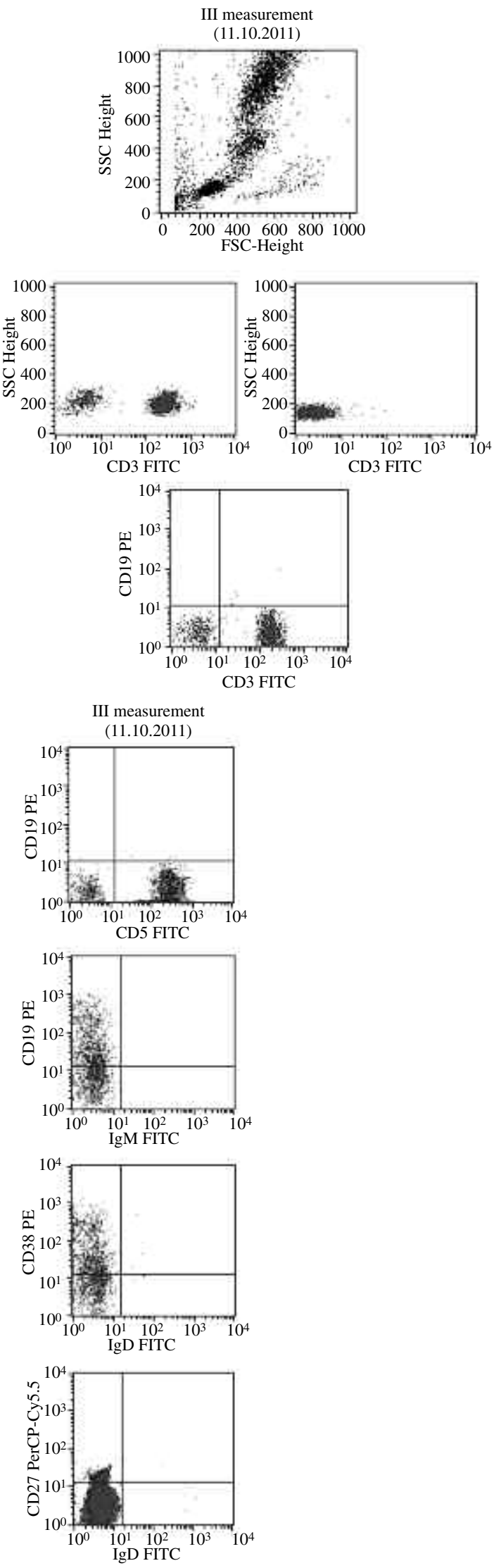

Fig. 1. Phenotypes of peripheral B cells of the patient in the first and third measurement. PBMCs were stained for the expression of CD3, CD5, CD19, CD27, CD38, IgM, and IgD and analyzed by flow cytometer. Analysis was performed by gating on CD19+cells, and dead cells were excluded by forward/side scatter gating 
$4.3 \mathrm{mg} / \mathrm{l}$. The staging results were Rai stage 2 and Binet stage A and the patient was ZAP-70 and CD38 negative.

The patient from October 2010 to March 2011 received 6 cycles of FCR chemotherapy with positive improvement. FCR regimen was chosen as an initial treatment strategy due to its remarkably higher potential of preventing disease progression in younger, healthier, treatment-naive CLL patients [2]. After the 6th cycle, the patient's WBC was $4.34 \times 10^{3} / \mathrm{mm}^{3}$ with lymphocytes count $1.48 \times$ $\times 10^{3} / \mathrm{mm}^{3}$ and PMNs count $2.02 \times 10^{3} / \mathrm{mm}^{3}$. From that time, his complete blood count was checked monthly, but despite progressive lymphopenia, the globulin levels were not checked.

The described man enrolled at Immunological Outpatient Clinic in July 2011 in order to assess his immunological status and receive preventive vaccination against selected pathogens after the treatment of CLL (18 weeks treatment-free period). Patient did not report any signs or symptoms suggesting the occurrence of the immunological disturbances during and after the end of chemotherapy. At the time of patient's submission, main laboratory test findings included leukopenia $-3.42 \times 10^{3} / \mathrm{mm}^{3}$ (lymphopenia
$-0.83 \times 10^{3} / \mathrm{mm}^{3}$ and neutropenia $\left.1.86 \times 10^{3} / \mathrm{mm}^{3}\right)$ and low serum levels of $\gamma$-globulin (IgG $-477 \mathrm{mg} / \mathrm{dl}$, IgA $48 \mathrm{mg} / \mathrm{dl}, \mathrm{IgM}-36 \mathrm{mg} / \mathrm{dl}$ ) with red blood cells and platelets parameters in normal ranges $\left(\mathrm{RBC}-5.07 \times 10^{6} / \mathrm{mm}^{3}\right.$, hemoglobin $-15.1 \mathrm{~g} / \mathrm{dl}$, hematocrit $-41.8 \%$, platelet count $-265 \times 10^{3} / \mathrm{mm}^{3}$ ).

Flow cytometric analyses (FACSCalibur cytometer with Cell-Quest Software; Becton Dickinson and relevant monoclonal antibodies; Pharmingen) presented gradually lowering levels of B lymphocytes (Fig. 1) and alteration in other cells subsets (Table 1), irrespective of no drug intake.

At the end of September 2011, the patient developed knee arthritis without any injury or purulent changes on the skin and was treated with the use of oral amoxicillin in the dose of $1 \mathrm{~g} / 24 \mathrm{~h}$ and clindamycin in a dose of $1.2 \mathrm{~g} / 24 \mathrm{~h}$ with no results. Therefore patient received treatment with the use of intravenous ceftriaxone $1 \mathrm{~g} / 12 \mathrm{~h}$ for the period of 10 days. A progressive neutropenia with lymphopenia and hypogammaglobulinemia persisted, leading to the necessity of gamma globulin supplementation and administration of granulocyte colony-stimulating factor (Fig. 2).

Table 1. Percentages and absolute numbers of lymphocyte subsets over 11 weeks of follow-up

\begin{tabular}{|c|c|c|c|c|c|c|}
\hline \multirow[t]{2}{*}{$\begin{array}{l}\text { Lymphocyte } \\
\text { subset }\end{array}$} & \multicolumn{2}{|c|}{$\begin{array}{c}\text { I measurement } \\
(22.07 .2011)\end{array}$} & \multicolumn{2}{|c|}{$\begin{array}{c}\text { II measurement } \\
(6.09 .2011)\end{array}$} & \multicolumn{2}{|c|}{$\begin{array}{l}\text { III measurement } \\
(11.10 .2011)\end{array}$} \\
\hline & $\begin{array}{c}\% \text { of all } \\
\text { lymphocytes }\end{array}$ & $\begin{array}{c}\text { absolute } \\
\text { count }(/ \mu \mathrm{l})\end{array}$ & $\begin{array}{c}\% \text { of all } \\
\text { lymphocytes }\end{array}$ & $\begin{array}{c}\text { absolute } \\
\text { count }(/ \mu \mathrm{l})\end{array}$ & $\begin{array}{c}\% \text { of all } \\
\text { lymphocytes }\end{array}$ & $\begin{array}{l}\text { absolute } \\
\text { count }(/ \mu \mathrm{l})\end{array}$ \\
\hline CD19+ & 0.59 & 5 & 0.34 & 3 & 0.04 & 0 \\
\hline $\mathrm{CD}^{+}{ }^{+} \mathrm{CD} 19^{+}$ & 0.22 & 2 & 0.12 & 1 & 0.01 & 0 \\
\hline $\mathrm{CD} 19^{+} \mathrm{CD} 25^{+}$ & 0.12 & 1 & 0.1 & 1 & 0.02 & 0 \\
\hline $\mathrm{CD} 19^{+} \mathrm{CD} 9^{+}$ & 0.15 & 1 & 0.09 & 1 & 0.03 & 0 \\
\hline $\mathrm{CD}^{+}+$ & 78.58 & 652 & 76.09 & 632 & 79.87 & 535 \\
\hline $\mathrm{CD}^{+}{ }^{+} \mathrm{CD}^{+}{ }^{+}$ & 39.61 & 329 & 32.44 & 269 & 39.51 & 265 \\
\hline $\mathrm{CD}^{+}{ }^{+} \mathrm{CD} 3^{+}$ & 39.99 & 332 & 45.07 & 374 & 39.98 & 268 \\
\hline $\begin{array}{l}\text { CD4/CD8 T } \\
\text { lymphocytes ratio }\end{array}$ & 0.99 & - & 0.72 & - & 0.99 & - \\
\hline $\mathrm{CD}^{+}{ }^{+} \mathrm{CD} 25^{+}$ & 17.91 & 149 & 12.36 & 103 & 17.19 & 115 \\
\hline $\mathrm{CD}^{+}{ }^{+} \mathrm{CD} 69^{+}$ & 1.05 & 9 & 4.88 & 41 & 7.54 & 51 \\
\hline $\mathrm{CD}^{+}{ }^{+} \mathrm{HLA}-\mathrm{DR}+$ & 35.22 & 292 & 33.41 & 277 & 35.57 & 238 \\
\hline $\mathrm{CD} 4{ }^{+} \mathrm{CD} 25^{+}$ & 17.37 & 144 & 11.05 & 92 & 17.88 & 120 \\
\hline $\mathrm{CD} 4^{+} \mathrm{CD} 25^{+ \text {high }}$ & 3.61 & 30 & 0.87 & 7 & 2.51 & 17 \\
\hline 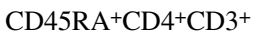 & 12.3 & 102 & 13.87 & 115 & 19.27 & 129 \\
\hline $\mathrm{CD} 4 \mathrm{RO}^{+} \mathrm{CD}^{+}{ }^{+} \mathrm{CD}^{+}$ & 88.2 & 732 & 90.61 & 752 & 85.82 & 575 \\
\hline $\mathrm{CD}^{3}+\mathrm{CD} 16+\mathrm{CD} 56+$ & 3.57 & 30 & 5.86 & 49 & 4.72 & 32 \\
\hline $\mathrm{CD}^{-}{ }^{-} \mathrm{CD} 16^{+} \mathrm{CD}^{-} 6^{+}$ & 12.16 & 101 & 14.07 & 117 & 13.56 & 91 \\
\hline
\end{tabular}



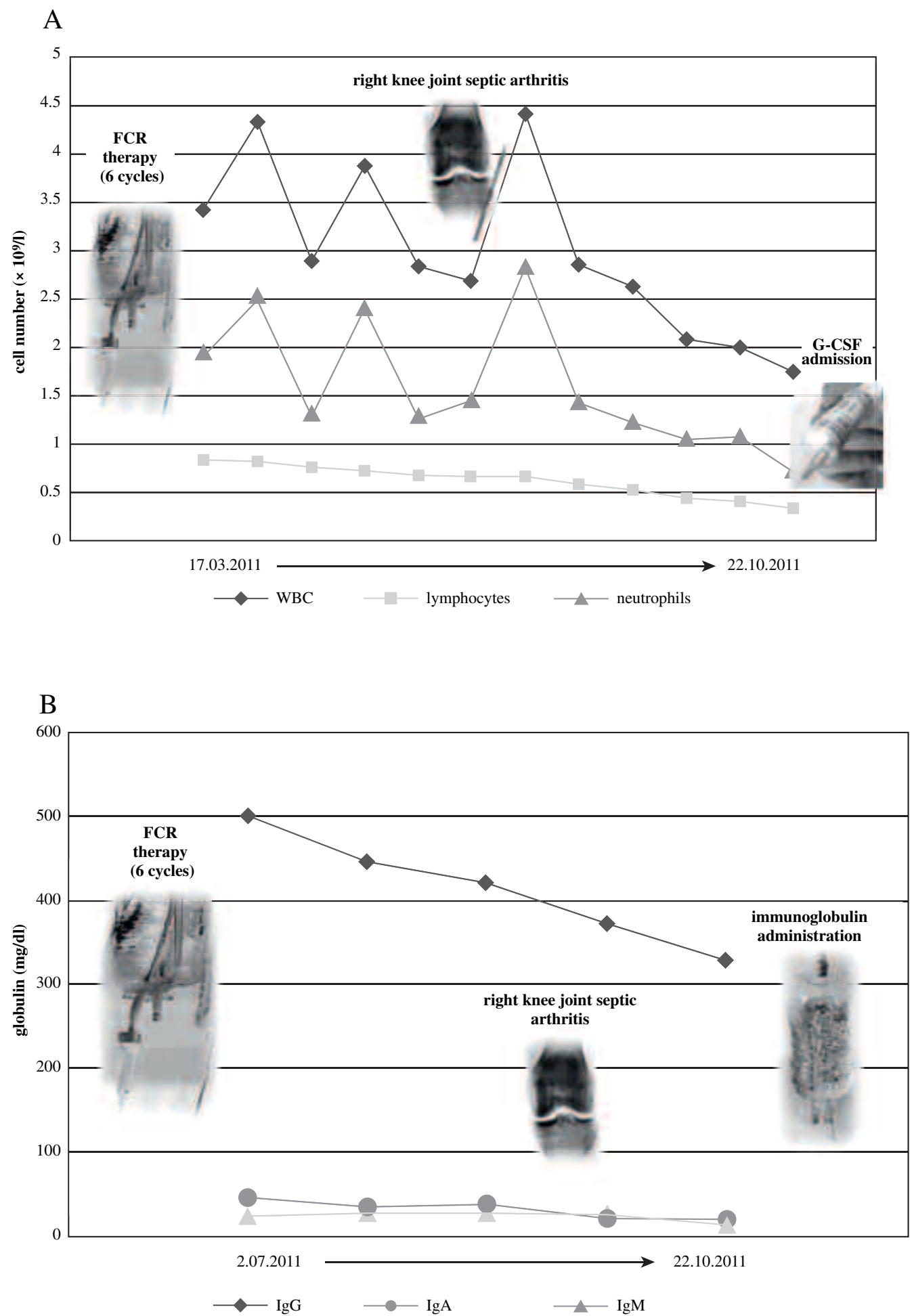

Fig. 2. A - the levels of WBC, lymphocytes and neutrophils in peripheral blood of the patient from the time of the end of the treatment to the G-CSF admission moment. B - serum immunoglobulin concentrations from the time of patient's admission to the Immunological Outpatient Clinic to the beginning of intravenous immunoglobulin (IVIG) supplementation 


\section{Discussion}

\section{Rituximab - mechanisms of acting}

Rituximab (RTX) is a human immunoglobulin G1-א antibody conjugated with mouse variable regions isolated from a murine anti-CD20 monoclonal Ab. It is the first monoclonal antibody successfully developed for treatment of malignant hematologic diseases [3]. The drug seems to act mainly by causing antibody dependent cell-mediated cytotoxicity (ADCC) [4] ultimately resulting in the lysis of target $\mathrm{B}$ cells [5]. Complement activation leading to the cytotoxicity is another mechanism of action of RTX [6]. The last important mechanism is binding of rituximab to CD20, which can induce intracellular signals resulting in programmed cell death $[7,8]$. The expression of CD20 begins at the pre-B cell stage and is lost prior to differentiation into immunoglobulin-secreting plasma cells $[9,10]$. Thus, RTX should not affect hematopoietic progenitor cells and mature, antibody-secreting plasma cells. Despite the B-cell depleting, the T-cell compartment may also be modulated by RTX [11].

\section{Rituximab related B-cell depletion - a common finding?}

Transient peripheral B cell depletion is common after the end of RTX therapy and appears during the treatment, but immunoglobulin levels are generally not affected due to the fact that CD20 is expressed on pre-B and mature B lymphocytes but not on stem cells or plasma cells [9-11]. However our observations are in line with the results of Nishio et al., who described 14 patients treated with rituximab as an adjuvant therapy [12]. Six persons developed hypogammaglobulinemia. A phenotypical analysis revealed a severe delay in the recovery of $\mathrm{CD} 27^{+}$memory B cells, especially in the $\mathrm{IgD}^{-} / \mathrm{CD} 27^{+}$switched populations and these data suggested that RTX can affect the B-cell quantities as well as B-cell repertoires [12]. Irie et al. [11] similarly to us found out that after RTX therapy may cause a reduction of classswitched $\mathrm{CD}_{27}{ }^{+} \operatorname{IgM}{ }^{-} \mathrm{IgD}^{-}$memory B cells. Keating et al. [13] reported that two-thirds of patients evaluated with flow cytometry had less than $1 \% \mathrm{CD}^{+} / \mathrm{CD} 19^{+}$cells in bone marrow after FCR therapy which provided that the progressionfree survival was significantly longer in the FCR group than in the FC group. Recovery of normal B cells usually occurs more than 6 months after therapy [14].

In our study, in observation period (July-October) we noticed $20 \%$ reduction of IgG level together with over than $90 \%$ B-lymphocyte count decrease. This finding is similar to the results obtained by Diwarak et al. [15], who found out in two adult patients with pre-existing primary antibody deficiency treated with various immunosuppressive agents due to idiopathic thrombocytopenic purpura without any notable infective problems but a few weeks after treatment with RTX, these patients presented with clinically significant immunodeficiency requiring intravenous immunoglobulin replacement therapy. CLL causing secondary immunodeficiency seems to induce the same problem.

\section{Single separate cases of other transient hematologic toxicity}

Lymphopenia may also be induced by fludarabine. Purine analogs are associated with lymphocytopenia, especially in absolute CD4 cell counts. Mentioned defect may persist for several years, while other mononuclear cell populations, such as B cells, recover more rapidly [16]. Fludarabine may also produce neutropenia in CLL or lowgrade lymphoma patients, pretreated with chemotherapeutic agents [17].

Late-onset neutropenia following RTX therapy is not an unusual finding in both lymphoma and autoimmune disorders patients $[18,19]$. In our patient, progressive lateonset neutropenia appeared together with lymphopenia and panhypogammaglobulinemia, what previously was not noticed. Neutropenia is observed with RTX therapy especially in cases of combined treatment with chemotherapy [20-22]. Delayed neutropenia has been described in rituximab-treated CLL patients. However among reported cases, the late onset and progressive leukopenia was not reported.

\section{Hypogammaglobulinemia in chronic lymphocytic leukemia}

The majority of patients with CLL develop hypogammaglobulinemia in the course of the disease [23, 24]. Zhu et al. [25] revealed that among 83 CLL patients, the IgG, IgA and IgM levels were reduced in 12, 26 and 34 cases, respectively. The incidence of $\mathrm{Ig}$ reduction was higher in Binet $\mathrm{C}$ stage than that in Binet A and B. Ig levels were not checked in our patient before his admission to Immunological Outpatient Clinic, however before initiation of the treatment he was in Binet stage A and had no clinical manifestations of hypogammaglobulinemia. Therefore it is to be supposed that his humoral immunity state was not affected. According to guidelines prepared by experts in the field of CLL, Prof. Rai and Prof. Keating, in patients who demonstrate a serum $\operatorname{IgG}<500 \mathrm{mg} / \mathrm{dl}$ and who have had recurrent infections requiring intravenous antibiotics or hospitalization, administration of intravenous immunoglobulin is recommended. The usual dose amounts to 200 to $400 \mathrm{mg} / \mathrm{kg}$, given at three- to four-week intervals. Serum IgG should be monitored in CLL patients due to its importance for evaluating immunologic state and susceptibility for infections. Even in successfully treated patients, there is rarely recovery of Ig levels [26]. Interestingly, Alexandrescu et al. suggested that use of high doses of rituximab can improve immune dysfunction and restore, in part, the production of immunoglobulins [27]. This issue has to be clarified in further studies. 


\section{Conclusions}

The present findings suggests that FCR therapy in some individuals may lead to the induction of progressive alteration of the cellular and humoral immunity leading to the development of pathologies similar to those found in common variable immunodeficiency. Therefore the levels of immunoglobulins should be regularly and frequently monitored before, during and after RTX treatment and in case of reduced $\mathrm{IgG}$ concentration, replacement therapy have to be considered especially when symptomatic infections appear. The lasting effects of rituximab on both the humoral and cellular arm of the immune system need further investigation. A long-term prospective study on patients who were treated with FCR regimen due to CLL have to be conducted for explaining the issue of post-FCR lymphopenia and hypogammaglobulinemia. Research should clarify how often progressive and late-onset aforementioned adverse events appear and which predictors are responsible for the observed effect.

This study was supported by research grant No. 2011/01/N/NZ6/01762 from National Science Centre, Poland.

\section{References}

1. Robak T (2010): Improving FCR immunochemotherapy in CLL. Blood 115: 437-438.

2. Cheng MM, Goulart B, Veenstra DL, et al. (2012): A network meta-analysis of therapies for previously untreated chronic lymphocytic leukemia. Cancer Treat Rev: http://dx.doi.org/ 10.1016/j.ctrv.2012.02.006.

3. Baleydier F, Domenech C, Thomas X (2011): Novel conventional therapies in onco-hemathology. Bull Cancer 98: 901-913.

4. Hamaguchi Y (2009): Molecular mechanisms of B lymphocyte depletion by CD20 immunotherapy. Nihon Rinsho Meneki Gakkai Kaishi 32: 29-34.

5. Glennie MJ, French RR, Cragg MS, Taylor RP (2007): Mechanisms of killing by anti-CD20 monoclonal antibodies. Mol Immunol 44: 3823-3837.

6. Cragg MS, Glennie MJ (2004): Antibody specificity controls in vivo effector mechanisms of anti-CD20 reagents. Blood 103: 2738-2743.

7. Byrd JC, Kitada S, Flinn IW, et al. (2002): The mechanism of tumor cell clearance by rituximab in vivo in patients with Bcell chronic lymphocytic leukemia: evidence of caspase activation and apoptosis induction. Blood 99: 1038-1043.

8. Pescovitz MD (2006): Rituximab, an anti-cd20 monoclonal antibody: history and mechanism of action. Am J Transplant 6: 859-866.

9. Uchida J, Hamaguchi Y, Oliver JA, et al. (2004): The innate mononuclear phagocyte network depletes B lymphocytes through Fc receptor-dependent mechanisms during anti-CD20 antibody immunotherapy. J Exp Med 199: 1659-1669.

10. Golby S, Hackett M, Boursier L, et al. (2002): B cell development and proliferation of mature B cells in human fetal intestine. J Leukoc Biol 72: 279-284.

11. Irie E, Shirota Y, Suzuki C, et al. (2010): Severe hypogammaglobulinemia persisting for 6 years after treatment with rituximab combined chemotherapy due to arrest of B lymphocyte differentiation together with alteration of T lymphocyte homeostasis. Int J Hematol 91: 501-508.

12. Nishio M, Fujimoto K, Yamamoto S, et al. (2006): Hypogammaglobulinemia with a selective delayed recovery in memory $\mathrm{B}$ cells and an impaired isotype expression after rituximab administration as an adjuvant to autologous stem cell transplantation for non-Hodgkin lymphoma. Eur J Haematol 77: 226-232.

13. Keating MJ, O'Brien S, Albitar M, et al. (2005): Early results of a chemoimmunotherapy regimen of fludarabine, cyclophosphamide, and rituximab as initial therapy for chronic lymphocytic leukemia. J Clin Oncol 23: 4079-4088.

14. McLaughlin P, Grillo-Lopez AJ, Link BK, et al. (1998): Rituximab chimeric anti-CD20 monoclonal antibody therapy for relapsed indolent lymphoma: half of patients respond to a fourdose treatment program. J Clin Oncol 16: 2825-2833.

15. Diwakar L, Gorrie S, Richter A, et al. (2010): Does rituximab aggravate pre-existing hypogammaglobulinaemia? J Clin Pathol 63: 275-277.

15. Tesfa D, Ajeganova S, Hägglund H, et al. (2011): Late-onset neutropenia following rituximab therapy in rheumatic diseases: association with B lymphocyte depletion and infections. Arthritis Rheum 63: 2209-2214.

16. Cheson BD (1995): Infectious and immunosuppressive complications of purine analog therapy. J Clin Oncol 13(9): 2431-2448.

17. Solal-Céligny P, Brice P, Brousse N, et al. (1996): Phase II trial of fludarabine monophosphate as first-line treatment in patients with advanced follicular lymphoma: a multicenter study by the Groupe d'Etude des Lymphomes de l'Adulte. J Clin Oncol 14: 514-519.

18. Hincks I, Woodcock BE, Thachil J (2011): Is rituximabinduced late-onset neutropenia a good prognostic indicator in lymphoproliferatve disorders? Br J Haematol 153: 411-413.

19. Tesfa D, Ajeganova S, Hägglund H, et al. (2011): Late-onset neutropenia following rituximab therapy in rheumatic diseases: association with B lymphocyte depletion and infections. Arthritis Rheum 63: 2209-2214.

20. James DF, Kipps TJ (2011): Rituximab in chronic lymphocytic leukemia. Adv Ther 28: 534-554.

21. Robak T, Dmoszynska A, Solal-Céligny P, et al. (2010): Rituximab plus fludarabine and cyclophosphamide prolongs progression-free survival compared with fludarabine and cyclophosphamide alone in previously treated chronic lymphocytic leukemia. J Clin Oncol 28: 1756-1765.

22. O'Brien S (2011): Survival advantage in CLL with frontline FCR therapy. Curr Hematol Malig Rep 6: 3-4.

23. Tsai HT, Caporaso NE, Kyle RA, et al. (2009): Evidence of serum immunoglobulin abnormalities up to 9.8 years before diagnosis of chronic lymphocytic leukemia: a prospective study. Blood 114: 4928-4932.

24. Morrison VA (2010): Infectious complications of chronic lymphocytic leukaemia: pathogenesis, spectrum of infection, preventive approaches. Best Pract Res Clin Haematol 23: $145-153$.

25. Zhu YD, Xu W, Miao KR, et al. (2009): Abnormality of serum immunoglobulin in peripheral blood of patients with chronic lymphocytic leukemia. Zhongguo Shi Yan Xue Ye Xue Za Zhi 17: 1159-1162.

26. Dearden C (2008): Disease-specific complications of chronic lymphocytic leukemia. Hematology Am Soc Hematol Educ Program: 450-456.

27. Alexandrescu DT, Wiernik PH (2008): Serum globulins as marker of immune restoration after treatment with high-dose rituximab for chronic lymphocytic leukemia. Med Oncol 25: $309-314$. 